\title{
Amyloid- $\beta$-Induced Ion Flux in Artificial Lipid Bilayers and Neuronal Cells: Resolving a Controversy
}

\author{
Ricardo Capone · Felipe Garcia Quiroz • Panchika Prangkio • \\ Inderjeet Saluja · Anna M. Sauer · Mahealani R. Bautista • \\ Raymond S. Turner · Jerry Yang $\cdot$ Michael Mayer
}

Received: 30 October 2008/Revised: 15 December 2008/ Accepted: 15 December 2008/Published online: 19 March 2009

(C) The Author(s) 2009. This article is published with open access at Springerlink.com

\begin{abstract}
Understanding the pathogenicity of amyloid-beta (A $\beta$ ) peptides constitutes a major goal in research on Alzheimer's disease (AD). One hypothesis entails that $\mathrm{A} \beta$ peptides induce uncontrolled, neurotoxic ion flux through cellular membranes. The exact biophysical mechanism of this ion flux is, however, a subject of an ongoing controversy which has attenuated progress toward understanding the importance of $\mathrm{A} \beta$-induced ion flux in $\mathrm{AD}$. The work presented here addresses two prevalent controversies regarding the nature of transmembrane ion flux induced by $\mathrm{A} \beta$ peptides. First, the results clarify that $\mathrm{A} \beta$ can induce stepwise ion flux across planar lipid bilayers as opposed to a gradual increase in transmembrane current; they show that the previously reported gradual thinning of membranes with concomitant increase in transmembrane current arises from residues of the solvent hexafluoroisopropanol, which is commonly used for the preparation of amyloid samples. Second, the results provide additional evidence suggesting that $\mathrm{A} \beta$ peptides can induce
\end{abstract}

R. Capone · F. G. Quiroz · P. Prangkio · A. M. Sauer Department of Biomedical Engineering, University of Michigan, 1101 Beal Ave, Ann Arbor, MI 48109-2110, USA

I. Saluja $\cdot$ R. S. Turner

Department of Neurology, University of Michigan,

Ann Arbor, USA

M. R. Bautista $\cdot$ J. Yang $(\square)$

Department of Chemistry and Biochemistry, University of California, San Diego, 9500 Gilman Drive, MC 0358, La Jolla, CA 92093-0358, USA

e-mail: jerryyang@ucsd.edu

M. Mayer ( $\square)$

Departments of Biomedical Engineering and Chemical

Engineering, University of Michigan, 1101 Beal Ave,

Ann Arbor, MI 48109-2110, USA

e-mail: mimayer@umich.edu ion channel-like ion flux in cellular membranes that is independent from the postulated ability of $\mathrm{A} \beta$ to modulate intrinsic cellular ion channels or transporter proteins.

Keywords Amyloid · Alzheimer's disease · Ion channel · Ion flux · Bilayer - Electrophysiology · Neurotoxicity · Membrane thinning · Hexafluoroisopropanol (HFIP) . SH-SY5Y cells

\section{Introduction}

One of the current hypotheses for the pathology of Alzheimer's disease $(\mathrm{AD})$ proposes that amyloid-beta $(\mathrm{A} \beta)$ peptides induce aberrant, neurotoxic ion flux across cellular membranes (Koh et al. 1990; Arispe et al. 1993a, b; Kawahara et al. 2000; Kourie et al. 2001; Michikawa et al. 2001; Arispe and Doh 2002; Kurganov et al. 2004; Barghorn et al. 2005; Quist et al. 2005; Baglioni et al. 2006; Devi et al. 2006; Morris and Juranka 2007; Palop et al. 2007; Simakova and Arispe 2007; Bezprozvanny and Mattson 2008). The resulting difficulty of neurons to regulate their intracellular concentration of ions, in particular calcium ions, has been associated with cell death (Khachaturian 1987; Mattson et al. 1992) and may thus contribute to cognitive impairment typical for AD. Understanding the underlying mechanisms that cause $\mathrm{A} \beta$-induced ion flux may hence be crucial for developing new strategies to reduce the toxicity of $\mathrm{A} \beta$ in $\mathrm{AD}$ (Inbar and Yang 2006; Inbar et al. 2006; Stains et al. 2007).

Increasing evidence shows that exposure of cells to $\mathrm{A} \beta$ leads to elevated concentrations of intracellular calcium ions (Khachaturian 1987, 1989; Mattson et al. 1992; Arispe et al. 1993b; Pollard et al. 1993; Kawahara et al. 2000; Mattson and Chan 2003; Demuro et al. 2005; Tu et al. 2006; Stutzmann 2007; Cheung et al. 2008; Nimmrich 
et al. 2008); the predominant cellular mechanism for this disruption of $\mathrm{Ca}^{2+}$ homeostasis remains, however, a focus of intense studies. The four mechanisms that have been proposed are (1) $\mathrm{A} \beta$ assembles into oligomers to form $\mathrm{A} \beta$ ion channels in cell membranes (Arispe et al. 1993a, b, 1996, 2007, 2008; Pollard et al. 1993; Durell et al. 1994; Mirzabekov et al. 1994; Kawahara et al. 1996, 1997; Rhee et al. 1998; Hirakura et al. 1999a, b; Lin et al. 1999, 2001; Zhu et al. 2000; Kourie et al. 2001, 2002; Kagan et al. 2002, 2004; Lin and Kagan 2002; Bahadi et al. 2003; Arispe 2004; Micelli et al. 2004; Mobley et al. 2004; Quist et al. 2005; Lal et al. 2007; Jang et al. 2008), (2) A $\beta$ interacts with membranes in such a way that it generally lowers the dielectric barrier for ions to cross the membrane (e.g. by thinning the membrane) (Kayed et al. 2004; Sokolov et al. 2004, 2006), (3) A $\beta$ modulates, directly or indirectly, the activity of existing ion channel proteins or receptors (Yankner et al. 1990a, b; Joslin et al. 1991; Mark et al. 1995; Querfurth et al. 1997; Ueda et al. 1997; Ye et al. 1997; Morimoto et al. 1998; Wang et al. 2000; Rovira et al. 2002; Dougherty et al. 2003; Novarino et al. 2004; Verdier et al. 2004; Deshpande et al. 2006; Stutzmann et al. 2006, 2007; Cheung et al. 2008; Dreses-Werringloer et al. 2008; Fedrizzi et al. 2008; Lopez et al. 2008; Nimmrich et al. 2008), or (4) A $\beta$ modulates, directly or indirectly, the activity of cellular ion transporters and pumps (Lam et al. 2001; Green et al. 2008). Experimental evidence for each of these mechanisms has been provided and it is possible that several mechanisms act together to disrupt $\mathrm{Ca}^{2+}$ homeostasis.

The work presented here examined the first three mechanisms. It employed electrophysiological techniques to measure ion flux by current recordings across bilayer lipid membranes (using BLM recordings) or across cellular plasma membranes (using whole-cell patch clamp recordings). This approach excluded the study of ion flux by transporter proteins or ion pumps because the ion flux generated by these proteins is too slow to be detectable by current recordings (Gennis 1989). Instead, we asked if A $\beta$ can form ion pores in artificial lipid bilayers, in membranes of a human neuronal cell line (SH-SY5Y), and in primary neurons from transgenic mice that generate $\mathrm{A} \beta$ intrinsically by expressing human amyloid precursor protein (hAPP) and human presenilin 1 (hPS-1).

\section{Materials and Methods}

\section{Chemicals}

We purchased $\mathrm{A} \beta(1-40)$ and $\mathrm{A} \beta(1-42)$ from Biopeptides Inc. and from Bachem Inc., hexafluoroisopropanol (HFIP) (GC grade) from Fluka, and the following seven lipids from Avanti Polar Lipids: 1-palmitoyl-2-oleoyl-sn-glycero-3- phosphoethanolamine (POPE), 1-palmitoyl-2-oleoyl-snglycero-3-[phospho-L-serine] (POPS), 1,2-dioleoyl-sn-glycero-3-phosphocholine (DOPC), 1,2-dioleoyl-sn-glycero-3phosphoethanolamine (DOPE), 1,2-dioleoyl-sn-glycero-3phosphoserine (DOPS), 1,2-diphytanoyl-sn-glycero-3-phosphocholine (DiPhyPC), 1-palmitoyl-2-oleoyl-sn-glycero-3[phospho-rac-(1-glycerol)] (POPG). All other chemicals were purchased from Sigma-Aldrich; SH-SY5Y cells were obtained from ATCC.

Preparation of Solutions of $\mathrm{A} \beta$ by Purging HFIP with Nitrogen Gas

We prepared samples of $\mathrm{A} \beta$ by following exactly a previously reported protocol (Kayed et al. 2003, 2004; Sokolov et al. 2004, 2006; Demuro et al. 2005). Briefly, we dissolved $1 \mathrm{mg}$ of $\mathrm{A} \beta$ peptide in $400 \mu \mathrm{l}$ of HFIP and incubated this solution for $15 \mathrm{~min}$. We mixed $100 \mu \mathrm{l}$ of the resulting, clear $\mathrm{A} \beta$ solution in HFIP with $900 \mu \mathrm{l}$ of deionized water in a siliconized $1.5 \mathrm{ml}$ microtube. After incubation at room temperature for $15 \mathrm{~min}$, we centrifuged the samples for $15 \mathrm{~min}$ at $14,000 \mathrm{~g}$ and transferred the supernatant fraction (900-950 $\mu \mathrm{l})$ to a new siliconized tube. To purge HFIP from these samples, we bubbled nitrogen gas for $10 \mathrm{~min}$ through these samples, while adjusting the gas flow to $\sim 30 \mathrm{ml} \mathrm{min}{ }^{-1}$, which was the maximum flow rate that did not result in excessive foaming and splashing of the sample. For purging times longer than $10 \mathrm{~min}$, we had to reduce the flow rate of the $\mathrm{N}_{2}$ gas to $2-3 \mathrm{ml} \mathrm{min}^{-1}$ in order to avoid significant loss of material due to slow but steady accumulation and expulsion of foam from the sample. We analyzed aliquots of these samples for residual HFIP concentration by gas chromatography-mass spectrometry (GCMS) and tested their ability to induce transmembrane ion flux in planar lipid bilayers and cell membranes.

\section{Quantification of HFIP Concentrations by GC-MS Analysis}

This analysis was carried out by injecting a sample volume of $2 \mu$ into a Finnigan Trace GC-MS with the following settings: run in electron impact ionization mode using a $30 \mathrm{~m}$ long, $0.25 \mathrm{~mm}$ ID Supelco SLB-5 column, with a film thickness of $0.25 \mu \mathrm{m}$. Helium was used as carrier gas at a constant flow rate of $1.0 \mathrm{ml} \mathrm{min}{ }^{-1}$; the injector temperature was $200^{\circ} \mathrm{C}$; the run was performed in split mode with a ratio of 1:100; the interface temperature was $250^{\circ} \mathrm{C}$, and the ion source block temperature was $220^{\circ} \mathrm{C}$. The temperature of the GC oven was held at $40^{\circ} \mathrm{C}$ for $2 \mathrm{~min}$ and then increased to $150^{\circ} \mathrm{C}$ at a rate of $40^{\circ} \mathrm{C} \mathrm{min}{ }^{-1}$. The MS ion source filament was set to an emission current of $150 \mu \mathrm{A}$ at $70 \mathrm{eV}$. HFIP standards and calibration curves were generated each day. Samples with unknown HFIP concentrations were measured 
using an external calibration curve; no internal standards were used. The quantification was based on the area under the GC peak in the chromatogram. Data were acquired and processed using Excalibur software, version 1.1.

\section{Formation of Planar Lipid Bilayers}

The two reported original procedures (Arispe et al. 1993b; Kayed et al. 2003) that are at the basis of the controversy regarding the nature of $\mathrm{A} \beta$-induced ion flux across artificial lipid membranes employed different methods to generate planar lipid bilayers (Arispe et al. 1993b; Kayed et al. 2004). We, therefore, prepared planar lipid bilayers [also called black lipid membranes or bilayer lipid membranes (BLMs)] either by the so-called "folding technique" (Montal and Mueller 1972; Mayer et al. 2003; Capone et al. 2007; Blake et al. 2008), which employs apposition of lipid monolayers over a pore with a diameter of $\sim 150 \mu \mathrm{m}$ in a Teflon film or by the so-called "painting technique" (Mueller et al. 1962; Capone et al. 2007), which applies a solution of lipids in decane or heptane over a pore with a diameter of $\sim 250 \mu \mathrm{m}$ in a Delrin septum.

For the folded bilayers (Figs. 1 and $2 \mathrm{~b}$ columns DOPC + DOPE and DiPhyPC), we pretreated the Teflon film with $2 \mu \mathrm{l}$ of $5 \%(\mathrm{v} / \mathrm{v})$ squalene in pentane and then formed the bilayers using $5 \mu$ of either pure DiPhyPC or a $1: 1(\mathrm{w} / \mathrm{w})$ mixture of a lipid solution in pentane that contained DOPC and DOPE. The total lipid concentration of these solutions in pentane was $20-25 \mathrm{mg} \mathrm{ml}^{-1}$ (Capone et al. 2007; Mayer et al. 2008). The electrolyte contained $70 \mathrm{mM} \mathrm{KCl}$ buffered with $10 \mathrm{mM}$ HEPES, pH 7.4.

For the painted bilayers, we used a bilayer cup (Warner Instruments, Delrin perfusion cup, volume $1 \mathrm{ml}$ ) and the following four lipid mixtures at a 1:1 (w/w) ratio: POPG: POPE in heptane, DOPS:POPE in heptane, DOPC:DOPE in heptane, or POPE:POPS in decane. The total lipid concentration of these solutions in heptane or decane was 10-20 $\mathrm{mg} \mathrm{ml}^{-1}$. In order to promote fusion of $\mathrm{A} \beta$ proteoliposomes into bilayers, we used an ionic gradient formed by filling the cis side (the side of proteoliposome addition) with $370 \mathrm{mM}$ $\mathrm{KCl}$ and the trans side of the bilayer setup with $70 \mathrm{mM} \mathrm{KCl}$. For these experiments, we prepared bilayers using a 1:1 (w/w) mixture of DOPC and DOPE (Fig. 1d) or POPC and POPE (Fig. 4a-c); the proteoliposomes containing $\mathrm{A} \beta$ were prepared as described previously using either a $1: 1(\mathrm{w} / \mathrm{w})$ mixture of DOPC and DOPE lipids (Fig. 1d) or pure POPS lipids (Fig. 4a, b and Fig. 5a) (Arispe et al. 1993b).

\section{Incorporation of $\mathrm{A} \beta$ into Lipid Membranes}

In order to repeat the procedure for preparing $\mathrm{A} \beta$ samples that was previously described to lead to membrane thinning of planar lipid bilayers (Kayed et al. 2004; Sokolov et al.
2004, 2006; Demuro et al. 2005), we prepared A $\beta$ samples by using the solvent HFIP exactly as described (Kayed et al. 2003) and added the resulting solutions to both compartments of the bilayer chamber. We diluted these samples more than 50-fold such that the final concentration of $\mathrm{A} \beta$ was $0.5-2.0 \mu \mathrm{M}$ in each chamber of the bilayer setup.

In order to repeat the alternative $\mathrm{A} \beta$ procedure, which was previously described to lead to stepwise ion flux across planar lipid bilayers (Arispe et al. 1993b), we added $10-20 \mu \mathrm{l}$ of the $\mathrm{A} \beta$ proteoliposome solution (this solution contained $\mathrm{A} \beta$ at a concentration of $0.4-0.8 \mathrm{mg} \mathrm{m}^{-1}$ ) to the cis compartment (volume $1 \mathrm{ml}$ ) and stirred for 5-10 min.

Planar lipid bilayer experiments with each lipid composition were performed at least 3 times, more typically 5-7 times.

\section{Current Recordings}

Before carrying out bilayer recordings, we verified that both the painted and the folded bilayers were stable for several minutes (while applying a voltage of at least $\pm 100 \mathrm{mV}$ ) and that the membrane capacitances were above $90 \mathrm{pF}$. When both criteria were fulfilled, we added $\mathrm{A} \beta(0.5-4.0 \mu \mathrm{M}$ final concentration of $\mathrm{A} \beta)$ or HFIP $(0.5-$ $7.0 \mathrm{mM}$ final concentration of HFIP without any $\mathrm{A} \beta$ present) to both chambers of the bilayer setup.

We performed all recordings in "voltage clamp mode" using $\mathrm{Ag} / \mathrm{AgCl}$ electrodes. We used a filter-cutoff frequency of $2 \mathrm{kHz}$, and a sampling frequency of $15 \mathrm{kHz}$ for all bilayer recordings. For representation in figures, we filtered the current traces with a digital Gaussian low-pass filter with a cutoff frequency of $100 \mathrm{~Hz}$.

For whole-cell patch clamp recordings, we used the following three solutions: (1) intracellular solution containing $75 \mathrm{mM} \mathrm{KCl}, 10 \mathrm{mM} \mathrm{NaCl}, 70 \mathrm{mM} \mathrm{KF}, 2 \mathrm{mM}$ $\mathrm{MgCl}_{2}, 10 \mathrm{mM}$ EGTA, and $10 \mathrm{mM}$ HEPES buffer (pH 7.2); (2) extracellular solution containing $160 \mathrm{mM} \mathrm{NaCl}$, $4.5 \mathrm{mM} \mathrm{KCl}, 1 \mathrm{mM} \mathrm{MgCl} 2,2 \mathrm{mM} \mathrm{CaCl} 2,5 \mathrm{mM}$ D-glucose, and $10 \mathrm{mM}$ HEPES buffer (pH 7.4); and (3) a "seal enhancer" solution containing $80 \mathrm{mM} \mathrm{NaCl}, 3 \mathrm{mM} \mathrm{KCl}$, $10 \mathrm{mM} \mathrm{MgCl} 2,35 \mathrm{mM} \mathrm{CaCl}_{2}$ and $10 \mathrm{mM}$ HEPES/NaOH ( $\mathrm{pH}$ 7.4), which was added to the extracellular compartment to promote the formation of seals between the cells and the glass chip with electrical resistances higher than $1 \mathrm{G} \Omega$.

In order to introduce $\mathrm{A} \beta$ into membranes of SH-SY5Y cells, we first established whole-cell recording conditions followed by adding $\sim 5 \mu \mathrm{l}$ of extracellular solution containing $\mathrm{A} \beta$ to a volume of $\sim 20 \mu \mathrm{l}$ of extracellular solution (this $\mathrm{A} \beta$ solution was prepared without the use of HFIP by dissolving $\mathrm{A} \beta$ in extracellular solution and stirring this solution for $\sim 14 \mathrm{~h}$ at room temperature prior to use). The final concentration of $\mathrm{A} \beta$ in the extracellular solution during the recording was $\sim 10 \mu \mathrm{M}$. 
In order to measure the effect of $\mathrm{A} \beta$ and HFIP samples on SH-SY5Y cells or on primary neurons, we used a semiautomated, chip-based electrophysiology instrument (Port-apatch, Nanion Inc.) that allowed for recordings with seal resistances of 1-6 G $\Omega$ (Schmidt et al. 2000; Bruggemann et al. 2003; Estes et al. 2008). We held the voltage at $-80 \mathrm{mV}$ in the intracellular compartment versus ground in the extracellular compartment to measure $\mathrm{A} \beta$-induced ion flux. At this potential, SH-SY5Y cells did not show significant intrinsic ion channel activity. Samples containing A $\beta$ or HFIP were only added after confirming the stability of the recording (i.e., after observing a quiescent baseline for 3-5 min). For all wholecell recordings, we used a filter cutoff frequency of $1 \mathrm{kHz}$.

In order to determine the effect of $\mathrm{Zn}^{2+}$ ions or the peptide NA7 on $\mathrm{A} \beta$-induced transmembrane ion flux, we added 1-10 mM (final concentration) of $\mathrm{ZnCl}_{2}$ or $\mathrm{Zn}\left(\mathrm{NO}_{3}\right)_{2}$ or $100-140 \mu \mathrm{M}$ (final concentration) of the NA7 peptide to the bilayer chambers or to the extracellular solutions.

\section{Preparation of Primary Neurons}

Wild-type female mice (C57BL/6J) were crossed with double transgenic hAPPswe/hPS-1 $\Delta \mathrm{E} 9$ male mice, obtained from Jackson Laboratory (Bar Harbor, Maine) to generate wild-type, and hAPPswe/hPS-1 transgenic embryos. Primary cortical neuron cultures were prepared from the brains of E16 embryos. Briefly, the cerebral cortices were dissected in calcium-free and magnesium-free Hank's balanced salt solution and incubated with a $0.125 \%$ trypsin solution for $10 \mathrm{~min}$ at $37^{\circ} \mathrm{C}$. The trypsin was inactivated with Dulbecco's modified Eagle's medium containing $10 \%$ fetal bovine serum, and the cortical tissue was further dissociated by serial trituration using a Pasteur pipette. The resulting cell suspensions were diluted in neurobasal medium supplemented with B27 supplements (Gibco BRL, Grand Island, New York), and plated onto poly-D-lysinecoated Petri dishes. Neurons were maintained at $37^{\circ} \mathrm{C}$ in a $5 \% \mathrm{CO}_{2}$ atmosphere for 4-7 days, before the experiments (Saluja et al. 2006). We carried out the planar patch clamp experiments (on the Port-a-patch instrument) between day 4 and day 7 of culture. The neurons were detached using a protocol previously described and validated by Lecoeur et al. (2004) with minor modifications; these modifications entailed (1) reducing the incubation time with trypsinEDTA from 15 to $14 \mathrm{~min}$ at $37^{\circ} \mathrm{C}$ and (2) dissociating cell aggregates by increasing the number of successively aspirating and dispensing the cell suspension to 7 times with a $1 \mathrm{~mL}$ pipette tip and to 15 times with a $200 \mu \mathrm{l}$ pipette tip.

\section{Cytotoxicity Assay of HFIP with SH-SY5Y Cells}

We cultured SH-SY5Y human neuroblastoma cells in DMEM/F-12 (1:1) medium with $10 \%$ fetal bovine serum,
$4 \mathrm{mM}$ glutamax, penicillin (100 units $\mathrm{ml}^{-1}$ ) and streptomycin $\left(100 \mu \mathrm{g} \mathrm{ml}^{-1}\right)$ in $5 \% \mathrm{CO}_{2}$ at $37^{\circ} \mathrm{C}$. We plated cells in 96-well plates overnight starting with 50,000 cells well ${ }^{-1}$. After overnight incubation at $37^{\circ} \mathrm{C}$, we exchanged the media with OptiMEM, and treated cells for $24 \mathrm{~h}$. We determined the cell viability using an MTT toxicology kit (Tox-1, from Sigma) according to the instructions from the supplier.

\section{Results and Discussion}

Recently, three articles highlighted an ongoing controversy with regard to the exact biophysical characteristics of $\mathrm{A} \beta$-induced transmembrane ion flux across artificial lipid membranes (Eliezer 2006; Fagan et al. 2006; Marx 2007). These articles debate two mechanistic hypotheses. On the one hand, the "A $\beta$ ion channel hypothesis" suggests that $\mathrm{A} \beta$ assembles into pore-like structures in lipid membranes, leading to stepwise (or spike-like) fluctuations of transmembrane current that is typical for ion channels (Arispe et al. 1993a, b, 1996, 2007, 2008; Durell et al. 1994; Mirzabekov et al. 1994; Kawahara et al. 1996, 1997; Rhee et al. 1998; Hirakura et al. 1999a, b; Lin et al. 1999, 2001; Bhatia et al. 2000; Zhu et al. 2000; Kourie et al. 2001; Kagan et al. 2002, 2004; Kourie et al. 2002; Lin and Kagan 2002; Bahadi et al. 2003; Arispe 2004; Micelli et al. 2004; Quist et al. 2005; Lal et al. 2007; Jang et al. 2008). On the other hand, the " $\mathrm{A} \beta$ membrane thinning hypothesis" postulates a generalized and gradually increasing ion flux as a result of $\mathrm{A} \beta$-induced reduction of the dielectric barrier of membranes, for instance, by thinning of membranes (Kayed et al. 2004; Sokolov et al. 2004, 2006).

Here, we examined, in detail, the two pivotal protocols for measuring $\mathrm{A} \beta$-induced conductance through artificial lipid bilayers to resolve this controversy. The protocol that leads to ion flux by gradual membrane thinning involves solubilizing $\mathrm{A} \beta(1-40)$ or $\mathrm{A} \beta(1-42)$ in the solvent hexafluoroisopropanol (HFIP), followed by dilution in water, and purging of HFIP by a stream of nitrogen gas (Kayed et al. 2003, 2004; Sokolov et al. 2004, 2006; Demuro et al. 2005; Valincius et al. 2008). Figure 1a shows the gradual increase in ion flux through a planar lipid bilayer upon exposure of membranes to these $\mathrm{A} \beta$ samples. Figure $1 \mathrm{a}$ is consistent with previous reports that used the same HFIP-based experimental procedure (Kayed et al. 2004; Sokolov et al. 2004, 2006). Figure 1b, however, shows a similar gradual increase in conductance following the exact same protocol but in the absence of $\mathrm{A} \beta$. This control experiment thus shows that $\mathrm{A} \beta$ was not required for the observed gradual increase in transmembrane conductance but that 

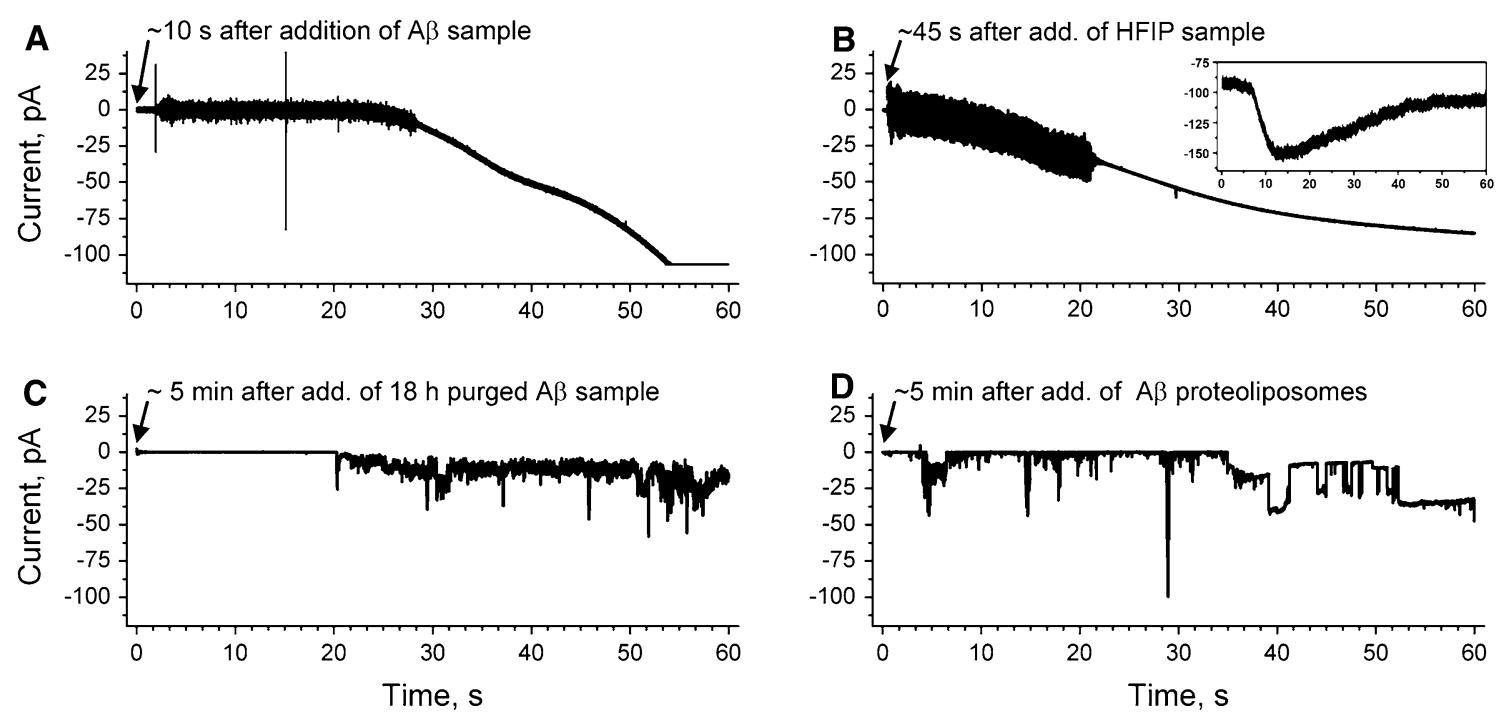

Fig. 1 Comparison of ion flux across lipid bilayers upon exposure to samples of amyloid- $\beta$ peptides $(\mathrm{A} \beta)$, which were prepared by two different protocols (final $\mathrm{A} \beta$ concentration $1 \mu \mathrm{M}$ ). a Gradual increase in transmembrane ion flux upon addition of an $\mathrm{A} \beta$ sample that was prepared by purging the solvent hexafluoroisopropanol (HFIP) for 10 min (Kayed et al. 2004; Sokolov et al. 2004). The "noisy" part of the current trace is a result of stirring. b Gradual increase in transmembrane ion flux following the exact same protocol as in (a) but in the absence of $\mathrm{A} \beta$. Inset shows gradual increase in ion flux across the membranes of SH-SY5Y cells upon addition of HFIP (final

residues of HFIP alone could be responsible for the observed ion flux. ${ }^{1}$

In order to investigate whether this gradual increase in conductance could be reproduced by exposure of membranes to defined concentrations of HFIP (in the absence of $\mathrm{A} \beta$ ), we examined the effect of HFIP on cell membranes (Fig. 1b inset) and on planar lipid bilayers of various lipid compositions (Fig. 2a, b). We found that, in all of these membranes, solutions containing 1-6 mM (corresponding to $0.01-0.06 \% \mathrm{v} / \mathrm{v}$ ) concentrations of HFIP induced a gradual increase in ion flux similar to the results shown in Fig. $1 \mathrm{~b}$ and similar to results described previously (Kayed

\footnotetext{
${ }^{1}$ One of the previously reported results that supported the hypothesis of $\mathrm{A} \beta$-induced gradual thinning of membranes was the observation that an anti-A $\beta$ antibody could reduce the observed transmembrane ion flux caused by these $\mathrm{A} \beta$ preparations. These experiments were carried out with $\mathrm{A} \beta$ samples that were also prepared with an HFIP purging protocol (Kayed et al. 2003, 2004; Sokolov et al. 2004, 2006). We repeated this experiment with the modification that we added bovine serum albumin (BSA) instead of adding an anti-A $\beta$ antibody. In approximately half of these trials, we found a reduction in transmembrane ion flux by adding BSA to the bilayer chamber. The results were thus similar to the effect attributed previously to the anti$\mathrm{A} \beta$ antibody. Furthermore, when we induced transmembrane ion flux by adding HFIP only, we observed again a reduction in conductance by addition of BSA to bilayer chambers that did not contain $\mathrm{A} \beta$. These results suggest that a specific anti-A $\beta$ antibody was not required to reduce gradually increasing ion flux that was induced by samples containing HFIP.
}

concentration $\sim 6 \mathrm{mM}$ ). $\mathrm{c}$ Transmembrane ion flux upon addition of an $\mathrm{A} \beta$ sample prepared according to previous reports (Kayed et al. 2004; Sokolov et al. 2004) but with $18 \mathrm{~h}$ instead of $10 \mathrm{~min}$ of purging to remove HFIP. d Stepwise fluctuations in transmembrane ion flux after incorporating a proteoliposome preparation of $\mathrm{A} \beta$ that was prepared without using HFIP (Arispe et al. 1993b). The applied voltage was $-150 \mathrm{mV}$ in all recordings. Membranes were prepared from DOPC:DOPE lipids at a $1: 1(\mathrm{w} / \mathrm{w})$ ratio by the "folding method" over a pore with a diameter of $150 \mu \mathrm{m}$ in a Teflon film that was pretreated with $5 \%$ squalene in pentane

et al. 2004; Sokolov et al. 2004, 2006). ${ }^{2}$ Since HFIP induced a significant, gradual increase in transmembrane ion flux in all tested membranes, we investigated its toxicity on SH-SY5Y cells using the MTT viability assay. We found that HFIP was toxic to SH-SY5Y cells in a dosedependent manner: a concentration of HFIP of $\sim 30 \mathrm{mM}$ $(\sim 0.3 \% \mathrm{v} / \mathrm{v})$ reduced the viability of SH-SY5Y cells to $50 \%$ (Fig. 3). At HFIP concentrations above $\sim 60 \mathrm{mM}$ $(\sim 0.6 \% \mathrm{v} / \mathrm{v})$, we observed a $90 \%$ reduction in viability of these cells. ${ }^{3}$ Based on these results, we emphasize that it is critically important to remove HFIP completely before attempting to investigate the effect of $\mathrm{A} \beta$, or other samples prepared with HFIP, on cytotoxicity or on bilayer membranes.

In order to examine the contribution of HFIP to the reported transmembrane ion flux across lipid bilayers in detail, we determined the residual concentration of HFIP after purging $\mathrm{A} \beta$ samples (Fig. 2c). In the previously described protocol of preparing $\mathrm{A} \beta$ samples by purging of

\footnotetext{
2 These results together with previous work (Ennaceur and Sanderson 2005) show that even low concentrations of HFIP can adversely affect membranes and alter their permeability for ions. Unlike other short chain alcohols, HFIP affects membranes similarly as long chain alcohols (Gutknecht and Tosteson 1970; Ueda and Yoshida 1999; Ebihara et al. 1979).

${ }^{3}$ For comparison, the ethanol concentration necessary to achieve similar cell toxicity is higher than $200 \mathrm{mM}$ (Luo and Miller 1997).
} 
Fig. 2 Transmembrane ion flux induced by samples containing welldefined concentrations of HFIP as well as removal of HFIP from $\mathrm{A} \beta$ samples as a function of the time of purging with nitrogen gas. a Current versus voltage curves of transmembrane ion flux as a function of HFIP concentration ( $\mathrm{A} \beta$ was not present in these experiments). The slopes of the linear best fits represent the conductance (in Siemens, $\mathrm{S}=\Omega^{-1}$ ) of ions across a planar lipid bilayer made from a 1:1 (w/w) mixture of DOPS and POPE. The absolute magnitudes of these conductance values varied between repeated experiments and between different membrane compositions; however, the relative dose-dependent effect of increasing concentration of HFIP on the conductance remained the same. b Transmembrane conductance induced by $1 \mathrm{mM}$ HFIP (equivalent to $0.01 \% \mathrm{v} / \mathrm{v}$ ) in planar lipid bilayers of various lipid compositions and by $\sim 6 \mathrm{mM}$ HFIP in cell membranes. All indicated lipid mixtures were prepared in a 1:1 (w/w) ratio. All experiments were repeated at least three times; the error bars represent the standard deviation from the mean conductance. c Removal of HFIP from samples containing $100 \mu \mathrm{l}$ of HFIP and $900 \mu \mathrm{l}$ of water (concentration of HFIP $\sim 1 \mathrm{M}$ ) as a function of purging time with nitrogen gas. The data indicated by red circles correspond to a flow rate of $\mathrm{N}_{2}$ gas of $\sim 30 \mathrm{ml} \mathrm{min}^{-1}$. The data indicated by black squares correspond to a flow rate of $2-3 \mathrm{ml} \mathrm{min}^{-1}$. All points represent average values ( \pm standard deviation) from 2 to 6 repeated experiments. Note, for purging times longer than $10 \mathrm{~min}$ with a flow rate of $\sim 30 \mathrm{ml} \mathrm{min}{ }^{-1}$, we observed that significant amounts of the foam that formed during purging escaped the microtube, thus rendering this fast flow rate impractical for purging times longer than $10 \mathrm{~min}$

HFIP (Kayed et al. 2003, 2004; Sokolov et al. 2004, 2006; Demuro et al. 2005; Valincius et al. 2008), the $\mathrm{A} \beta$ samples were subjected to a gentle stream of $\mathrm{N}_{2}$ gas for 5-10 min. We found by gas chromatography and mass spectrometry (GC-MS) analysis of $\mathrm{A} \beta$ samples prepared in the same fashion that the residual concentrations of HFIP exceeded $200 \mathrm{mM}$ in the $\mathrm{A} \beta$ samples (Fig. 2c) even after purging for $30 \mathrm{~min}$ at a flow rate of $2-3 \mathrm{ml} \mathrm{min}{ }^{-1}$ or after purging for $10 \mathrm{~min}$ at a fast flow rate of $\sim 30 \mathrm{ml} \mathrm{min}{ }^{-1}$ (purging times longer than $10 \mathrm{~min}$ at this fast flow rate were not practical since they led to loss of $\mathrm{A} \beta$ by excessive foam formation). Addition of these $\mathrm{A} \beta$ samples to planar lipid bilayers or to cell membranes led to a gradual increase in transmembrane ion flux that was similar to the one shown in Fig. 1b (the final concentration of HFIP in the bilayer chamber ranged from 5 to $20 \mathrm{mM}$ ). These results suggest that the reported gradual increase in conductance (Kayed et al. 2004; Sokolov et al. 2004, 2006) was due to incomplete removal of residual HFIP in these $\mathrm{A} \beta$ samples.

In contrast, when we purged HFIP from $\mathrm{A} \beta$ samples for $18 \mathrm{~h}$, we found that (1) the residual concentration of HFIP in the $\mathrm{A} \beta$ samples was consistently below $10 \mathrm{mM}$ and (2) that addition of these $\mathrm{A} \beta$ samples to membranes (which resulted in a final concentration of HFIP below $0.2 \mathrm{mM}$ ) did not result in a gradual increase in ion flux. Instead, we observed in $\sim 75 \%$ of these experiments a stepwise ion flux as reported previously by several research groups (Fig. 1c) (Arispe et al. 1993a, b, 1996, 2007, 2008; Mirzabekov et al. 1994; Kawahara et al. 1996; Rhee et al. 1998;
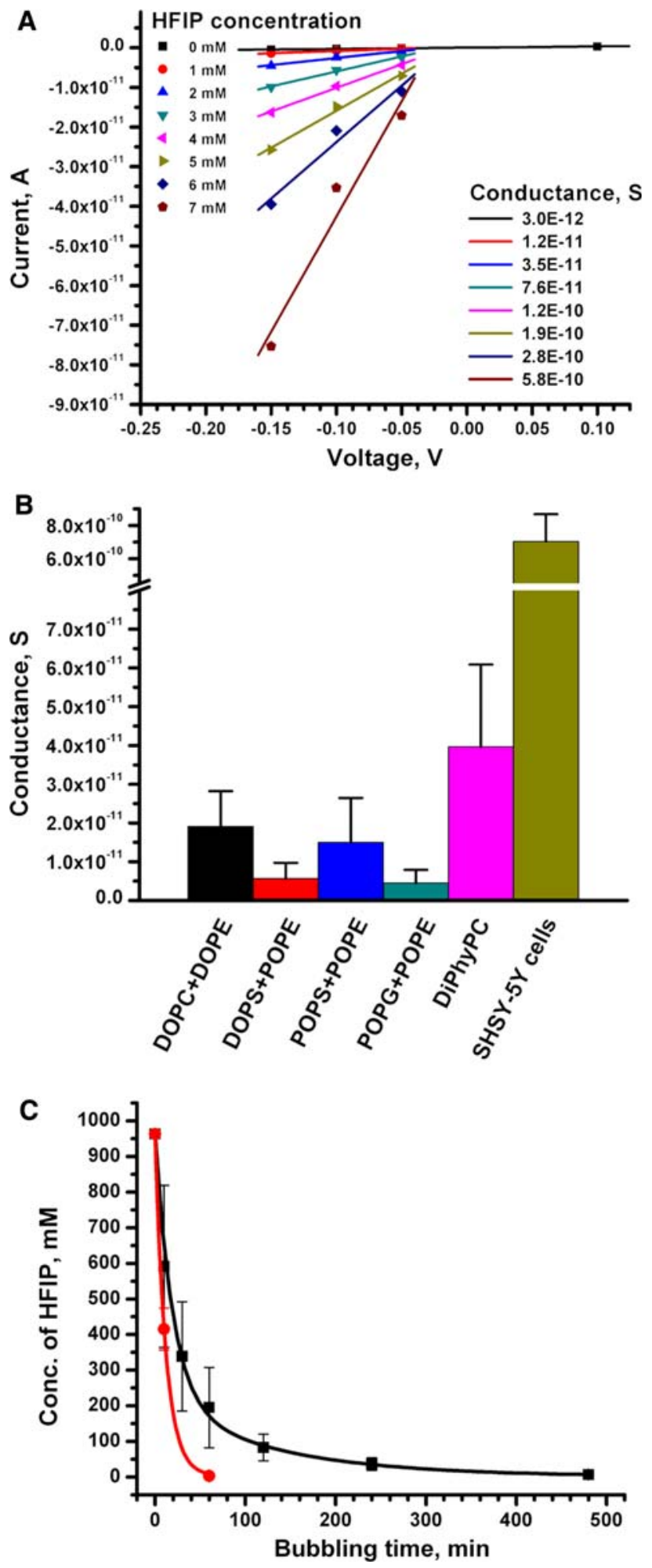

Hirakura et al. 1999a, b; Lin et al. 1999, 2001; Bhatia et al. 2000; Kourie et al. 2001; Kagan et al. 2002, 2004; Kourie et al. 2002; Lin and Kagan 2002; Bahadi et al. 2003; 


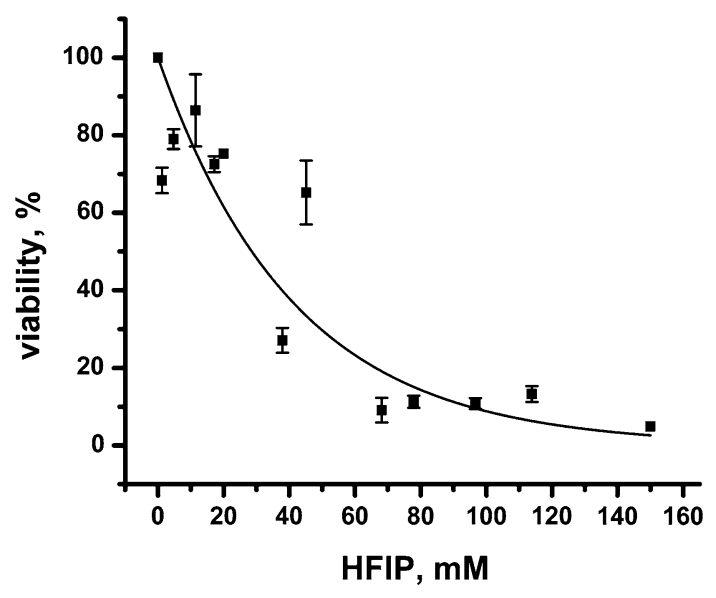

Fig. 3 Viability of human SH-SY5Y neuroblastoma cells as a function of overnight exposure to various increasing concentrations of HFIP. Data are represented relative to control cells that were treated the same way but without HFIP (corresponding to $100 \%$ viability). The solid curve represents a best fit to a first order exponential decay function of the form: Viability $(\%)=100 \% \times \mathrm{e}^{-([\mathrm{HFIP}]}$ in $\left.\mathrm{mM} /(41.2 \pm 1.2) \mathrm{mM}\right)$, $N=13, R^{2}=0.91$

Micelli et al. 2004; Quist et al. 2005). ${ }^{4}$ These ion channellike current fluctuations were reminiscent of the originally reported $\mathrm{A} \beta$-induced transmembrane ion flux that led to the $\mathrm{A} \beta$ ion channel hypothesis in AD (Arispe et al. 1993b; Pollard et al. 1993). For comparison, Fig. 1d shows such stepwise current fluctuations through planar lipid bilayers using the original protocol for preparation of $\mathrm{A} \beta$ samples (Arispe et al. 1993b) that did not employ HFIP (or that used a protocol for preparation of $\mathrm{A} \beta$ samples, which removed HFIP completely by lyophilization for 2 days prior to dissolving $\mathrm{A} \beta$ in aqueous solution).

The results presented here, along with evidence from other groups (Arispe et al. 1993a, b, 1996, 2007, 2008; Mirzabekov et al. 1994; Kawahara et al. 1996, 1997; Rhee et al. 1998; Hirakura et al. 1999a, b; Lin et al. 1999, 2001; Bhatia et al. 2000; Zhu et al. 2000; Kourie et al. 2001, 2002; Kagan et al. 2002, 2004; Lin and Kagan 2002; Bahadi et al. 2003; Arispe 2004; Micelli et al. 2004; Quist et al. 2005; Lal et al. 2007; Jang et al. 2008), clearly demonstrate that $\mathrm{A} \beta$ peptides are indeed capable of forming ion pores in artificial membranes. They also show that stepwise ion flux is the predominant mode of ion flux across artificial bilayers provided that the samples of $\mathrm{A} \beta$ are free of organic solvent. If gradual thinning would be the predominant mechanism of $\mathrm{A} \beta$-induced ion flux, then we would have expected to detect a gradual shift of the recorded current baseline under the same conditions where we observe measurable stepwise ion flux. Since all solventfree $\mathrm{A} \beta$ preparations that we tested did not lead to gradual

\footnotetext{
${ }^{4}$ In the remaining $\sim 25 \%$ of the trials, we observed a flat baseline without any detectable transmembrane current.
}

shifts in current baseline, we conclude that the postulated effect of $\mathrm{A} \beta$ to lower the dielectric barrier by gradual thinning of membranes-if existent-is small compared to the ion flux induced by $\mathrm{A} \beta$ pores. We also note that, to the best of our knowledge, all reports that observed gradual membrane thinning employed $\mathrm{A} \beta$ samples that were prepared with HFIP in combination with relatively short durations of purging $(<30 \mathrm{~min})$ by a gentle gas stream (Kayed et al. 2004; Sokolov et al. 2004, 2006). We, therefore, attribute the reported gradual increase in ion flux to residual HFIP in $\mathrm{A} \beta$ samples. This conclusion resolves the controversy with regard to $\mathrm{A} \beta$-induced ion flux across artificial lipid bilayers; the results presented here confirm that $\mathrm{A} \beta$ can form ion pores in bilayer membranes.

After establishing the stepwise nature of $\mathrm{A} \beta$-induced ion flux through planar lipid bilayers, two questions remain: (1) Can $\mathrm{A} \beta$ form ion pores in cellular membranes? (2) What is the predominant mechanism of $\mathrm{A} \beta$-induced ion flux across these cellular membranes? These questions are difficult to answer definitively because of the many direct and indirect pathways that can lead to ion flux in living cells. Here, we provide additional evidence in support of the hypothesis that $\mathrm{A} \beta$ is capable of forming independent pores in cellular membranes (Kawahara et al. 1997).

In order to compare ion flux induced by $\mathrm{A} \beta$ in artificial lipid bilayers with $\mathrm{A} \beta$-induced ion flux across cellular membranes, we performed whole-cell patch clamp recordings on a human neuroblastoma cell line (SH-SY5Y cells) that we exposed to an exogenously introduced $\mathrm{A} \beta$ preparation (prepared after completely removing HFIP by lyophylization for 2 days). In addition, we carried out whole-cell recordings from transgenic, primary neurons that produced $\mathrm{A} \beta$ endogenously. In both cell types, we performed all recordings close to the resting membrane potential of the cells (i.e., at a constant applied voltage of $-80 \mathrm{mV}$ ) in order to minimize the activity of voltage-gated ion channel proteins that are naturally (endogenously) expressed in cells.

Figure 4 shows stepwise (or spike-like) $\mathrm{A} \beta$-induced transmembrane ion flux in both cell types, regardless of whether $\mathrm{A} \beta$ was added exogenously to SH-SY5Y cells (Fig. 4d) or produced endogenously by transgenic primary neurons (Fig. 4g). It also demonstrates that both cell types showed no (or very rare) current fluctuations in the absence of $\mathrm{A} \beta$ (Fig. 4f, i). We performed 16 recordings of $\mathrm{A} \beta$-induced, channel-like ion flux on SH-SY5Y cells and observed ion flux in 12 experiments $(\sim 75 \%)$, while addition of $\mathrm{A} \beta$ induced no changes in ion flux in the remaining 4 experiments. Typically, $\mathrm{A} \beta$-induced current spikes occurred 5-15 min after addition of $\mathrm{A} \beta$, but in at least one recording the activity started within less than $30 \mathrm{~s}$, suggesting that $\mathrm{A} \beta$ can induce a measurable current flux quite rapidly. 

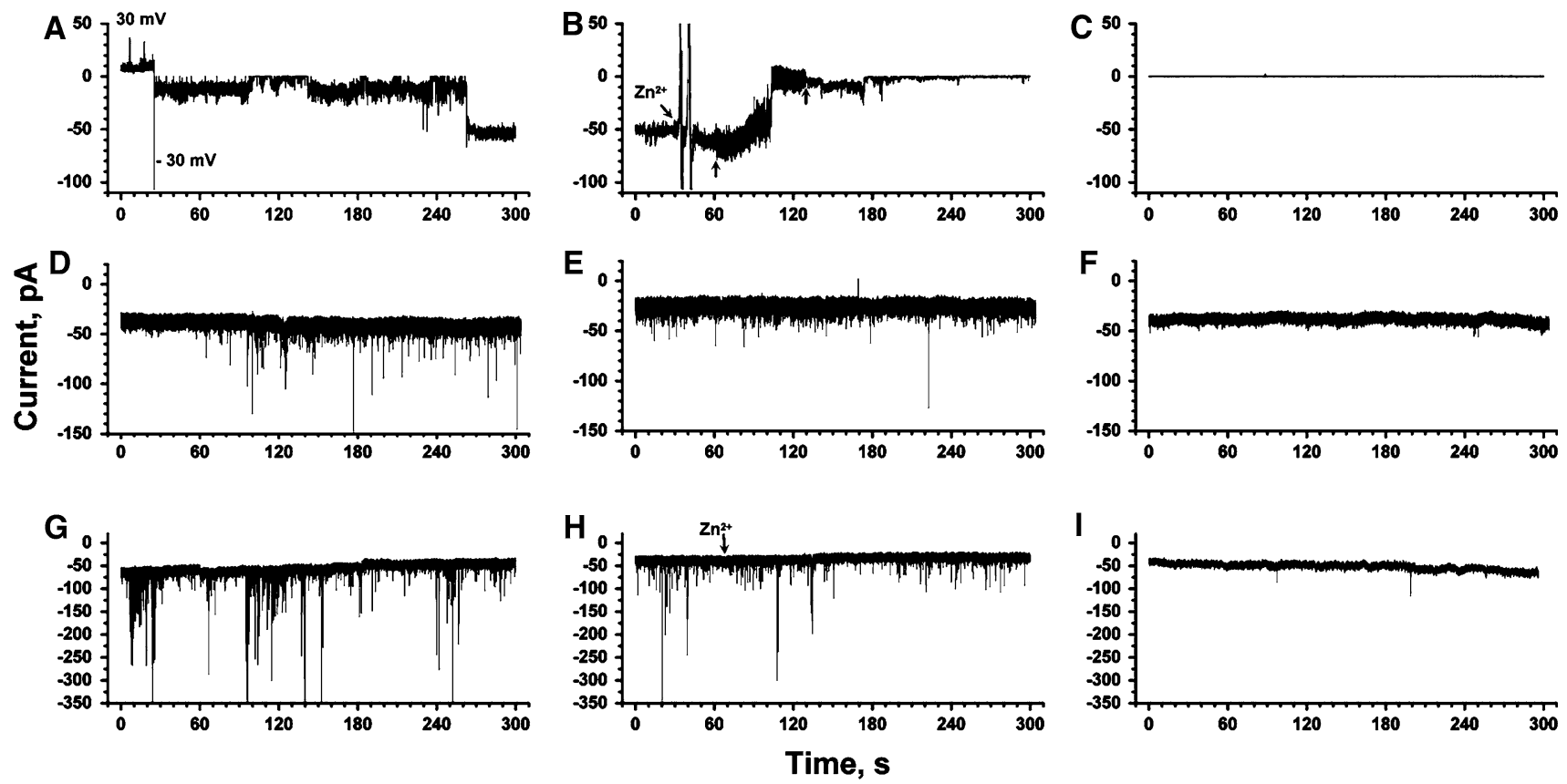

Fig. 4 Comparison of $\mathrm{A} \beta$-induced transmembrane ion flux across planar lipid bilayers, across plasma membranes of a neuroblastoma cell line, and across plasma membranes of primary cortical neurons from mouse embryos. a $\mathrm{A} \beta$-induced ion flux across a planar lipid bilayer (1:1 w/w POPC:POPE). A $\beta$ was introduced by proteoliposome fusion (final concentration of $\mathrm{A} \beta=1 \mu \mathrm{M}$ ). The applied potential was $+30 \mathrm{mV}$ or $-30 \mathrm{mV}$ as indicated. b Effect of the addition (arrow) of $\sim 3 \mathrm{mM} \mathrm{Zn}^{2+}$ on the same membrane as in (a). The small vertical arrows indicate the beginning and end of mixing. $\mathbf{c}$ Control experiment with a membrane of the same composition as in (a) and (b) but without $\mathrm{A} \beta$ present. d Whole-cell planar patch clamp recording of $\mathrm{A} \beta$-induced transmembrane currents across the plasma

In the case of the primary transgenic neurons, we recorded from eight cells that were extracted from three different transgenic embryos; seven of these recordings $(\sim 88 \%)$ showed a significant increase in the frequency of current spikes (Fig. 4g) compared to control recordings from wild-type neurons (Fig. 4i). Only 1 of 11 control recordings from primary, wild-type neurons showed a frequency in current fluctuations similar to transgenic neurons; the other 10 control cells displayed a significantly lower frequency of current spikes than transgenic neurons.

Since $\mathrm{Zn}^{2+}$ ions have previously been reported to block A $\beta$-induced stepwise ion flux (Arispe et al. 1996; Kawahara et al. 1997; Rhee et al. 1998; Lin et al. 1999; Kourie et al. 2001; Lin and Kagan 2002; Kagan et al. 2004), we added $\mathrm{Zn}^{2+}$ to determine its effect on the observed current fluctuations. In both, the SH-SY5Y and the transgenic cells, addition of $\mathrm{Zn}^{2+}$ reduced $\mathrm{A} \beta$-induced ion flux significantly (Fig. 4e, h). The inhibitory effect of $\mathrm{Zn}^{2+}$ in these two cell types was similar to the $\mathrm{Zn}^{2+}$-induced inhibition of $\mathrm{A} \beta$-induced, stepwise ion flux through artificial lipid bilayers (Fig. 4b). membrane of human neuroblastoma cells (SH-SY5Y). A $\beta$ was added to a final concentration of $\sim 10 \mu \mathrm{M}$ to the extracellular solution. The applied potential was $-80 \mathrm{mV}$. e Recording from the same cell and under the same conditions as in (d) but after addition of $\sim 2 \mathrm{mM}$ $\mathrm{Zn}^{2+}$ to the extracellular solution. $\mathrm{f}$ Control experiment of a wholecell recording from a SH-SY5Y cell in the absence of $\mathrm{A} \beta$ in the extracellular solution. g Whole-cell planar patch clamp recording from a primary cortical neuron of a transgenic mouse embryo that produced human $\mathrm{A} \beta$ endogenously. The applied potential was $-80 \mathrm{mV}$. h Effect of the addition of $\mathrm{Zn}^{2+}$ on a recording from the same cell as in $(\mathbf{g})$. i Control experiment with a wild-type cortical neuron that did not produce $\mathrm{A} \beta$

As mentioned above, control experiments, in which $\mathrm{A} \beta$ was neither introduced exogenously nor produced endogenously, did not result in significant stepwise or spike-like ion flux under the same experimental conditions (Fig. 4f, i), indicating that $\mathrm{A} \beta$ was required to induce measurable ion flux across cellular membranes. These results hence pose the question: Did this measurable ion flux result from activation of endogenous, cellular ion channel proteins or was it a consequence of self-assembly of $\mathrm{A} \beta$ to pores in cellular membranes?

A comparison of $\mathrm{A} \beta$-induced ion flux (Fig. 5) revealed that the average duration of stepwise (spike-like) current fluctuations was significantly longer in bilayer experiments than in cellular recordings (although bilayer experiments also revealed short-lived events). In contrast, the duration of $\mathrm{A} \beta$-induced current events was similar in SH-SY5Y cells compared to transgenic primary neurons. The frequency of large-amplitude current events (i.e., events that were larger than four times the standard deviation of the current noise) ranged from 0.2 to $5 \mathrm{~Hz}$ in SH-SY5Y and in transgenic cells to $\sim 10 \mathrm{~Hz}$ in bilayer experiments and was, thus, similar in magnitude. The single channel conductance 

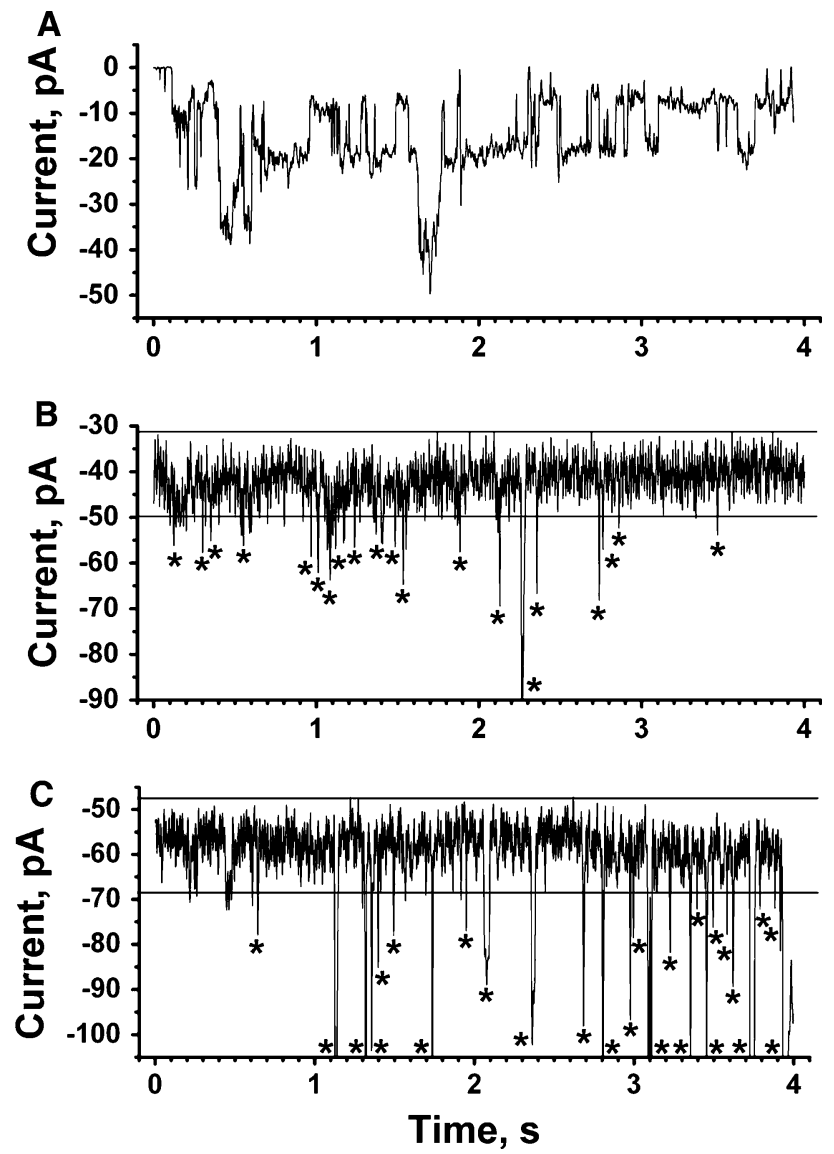

Fig. 5 Comparison of short recordings with expanded time axis of A $\beta$-induced ion flux across planar lipid bilayers, across plasma membranes of SH-SY5Y cells, and across plasma membranes of transgenic cortical neurons. a A $\beta$-induced ion flux through a planar lipid bilayer. The final concentration of $\mathrm{A} \beta$ was $10 \mu \mathrm{M}$ (applied potential $-30 \mathrm{mV}$ ). b $\mathrm{A} \beta$-induced ion flux through membranes of SH-SY5Y cells. The final concentration of $\mathrm{A} \beta$ was $\sim 10 \mu \mathrm{M}$ in the extracellular solution (applied potential $-80 \mathrm{mV}$ ). Current fluctuations significantly above baseline current noise are indicated with an asterisk. c $\mathrm{A} \beta$-induced ion flux through the plasma membranes of a cortical neuron that expressed $\mathrm{A} \beta$ (applied potential $-80 \mathrm{mV}$ ). Current fluctuations significantly above baseline current noise are indicated with an asterisk

of events ranged between 0.2 and $1.7 \mathrm{nS}$ in planar lipid bilayers and between 0.2 and $0.6 \mathrm{nS}$ in both SH-SY5Y cells and transgenic neurons. Although these conductance values are not directly comparable (since the ion concentrations and lipid compositions in the bilayer and cellular experiments could not be matched precisely), this comparison suggests that the conductance of $\mathrm{A} \beta$-induced stepwise ion flux in bilayers and live cells was on the same order of magnitude.

In order to minimize the possibility that endogenous, cellular ion channels would be activated by $\mathrm{A} \beta$, we performed all recordings close to the resting membrane potential $(-80 \mathrm{mV})$ and we added a mixture of ion channel blockers to the extracellular solution. This mixture included (final concentration in the extracellular solution): $20 \mathrm{mM}$ tetraethylammonium (TEA) ions to block potassium channels (Forsythe et al. 1992; Mathie et al. 1998; Tosetti et al. 1998; Guyon et al. 2005), $1 \mu \mathrm{M}$ tetrodotoxin to block sodium channels (Forsythe et al. 1992; Toselli et al. 1996; Guyon et al. 2005), $2 \mu \mathrm{M}$ nifedipine to block L-type calcium channels, and $2 \mu \mathrm{M} \omega$-conotoxin to block N-type calcium channels (McDonald et al. 1994, 1995; Reeve et al. 1994, 1995; Furukawa et al. 2003; Billups et al. 2006). Figure $6 \mathrm{a}$ shows that $\mathrm{A} \beta$-induced ion flux persisted in the presence of these blockers. Only the addition of $\mathrm{Zn}^{2+}$ caused a significant reduction in $\mathrm{A} \beta$-induced, large-amplitude current fluctuations in these cells. Since A $\beta$-induced, channel-like ion flux through artificial bilayers is blocked effectively by $\mathrm{Zn}^{2+}$ (Fig. 4b), the $\mathrm{Zn}^{2+}$-dependent blockage of ion flux shown in Fig. $6 \mathrm{a}$ suggests that $\mathrm{A} \beta$ is also capable of inducing ion channellike ion flux in live cells. These results do not exclude the
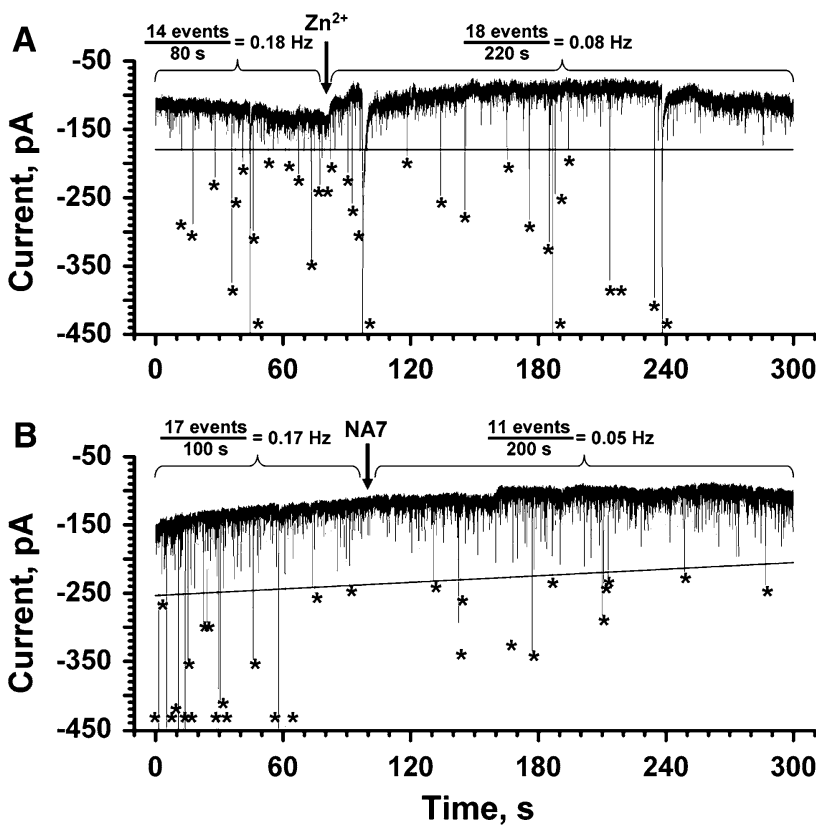

Fig. 6 Reduction of $\mathrm{A} \beta$-induced ion flux across the plasma membrane of SH-SY5Y cells by $\mathrm{Zn}^{2+}$ ions or NA7 peptides. a Effect of $\mathrm{Zn}^{2+}$ (final concentration $\sim 2 \mathrm{mM}$ ) on $\mathrm{A} \beta$-induced ion flux. Note these recordings were carried out in the presence of a mixture of ion channel blockers containing $20 \mathrm{mM}$ TEA, $1 \mu \mathrm{M}$ tetrodotoxin, $2 \mu \mathrm{M}$ nifedipine, and $2 \mu \mathrm{M} \omega$-conotoxin; these ion channel blockers did not affect $\mathrm{A} \beta$-induced ion flux but reduced the probability that intrinsic ion channels may be responsible for the observed current spikes. Large-amplitude current spikes, i.e. spikes with amplitudes above the threshold (black solid line), are indicated with an asterisk. The vertical arrow indicates the time point when $\mathrm{Zn}^{2+}$ was added. b Effect of NA7 peptide (final concentration $\sim 100 \mu \mathrm{M}$ ) on A $\beta$-induced transmembrane ion flux. Large-amplitude current spikes, i.e. spikes with amplitudes above the threshold (black solid line), are indicated with an asterisk. The vertical arrow indicates the time point when NA7 was added. Both recordings were carried out with an applied potential of $-80 \mathrm{mV}$ 
possibility that $\mathrm{A} \beta$ may activate endogenous cellular channels; these channels would, however, have to fulfill at least three characteristics: (1) they would have to be activated by $\mathrm{A} \beta$ at the resting potential of $-80 \mathrm{mV}$, (2) they would have to be insensitive to the cocktail of blockers, and (3) they would have to be sensitive to $\mathrm{Zn}^{2+}$ ions.

Since it is, in principle, possible that $\mathrm{Zn}^{2+}$ ions blocked endogenous, cellular ion channels, we also tested the effect of a specific blocker of $\mathrm{A} \beta$-induced transmembrane ion flux in these cell experiments. Arispe and coworkers reported that a peptide called NA7 (corresponding to the amino acid sequence EVHHQKL of residues 11 to 17 of $A \beta$ ) is an effective and specific blocker of $\mathrm{A} \beta$-induced, stepwise ion flux (Simakova and Arispe 2006; Arispe et al. 2007). When we tested this peptide in SH-SY5Y cells, we found, in three of four recorded cells, up to a threefold reduction in the frequency of large-amplitude current events induced by $\mathrm{A} \beta$ (Fig. 6b). This result further supports the hypothesis that $\mathrm{A} \beta$ can independently induce stepwise (or spike-like) ion flux across cellular membranes by self-assembly to pores or by inducing membrane defects.

In conclusion, the work presented here demonstrates that $\mathrm{A} \beta$ can cause stepwise transmembrane ion flux through artificial membranes. The previously postulated membrane thinning that was reported to lead to gradual increase in transmembrane ion flux is likely not attributable to $\mathrm{A} \beta$, but instead is due to residues of the solvent HFIP used to prepare samples of $\mathrm{A} \beta$. We found that HFIP is membraneactive and cytotoxic in the low millimolar range. Therefore, it is critical to remove HFIP in any amyloid samples before they are used in membrane or cellular studies. In addition, we present evidence that $\mathrm{A} \beta$ is capable of inducing stepwise transmembrane ion fluctuations in living cells. Although we cannot rule out the possibility that $\mathrm{A} \beta$ activates intrinsic ion channels or ion pumps in cells, the results presented here suggest that $\mathrm{A} \beta$ is capable of selfassembling into structures that either form a pore through membranes or generate transient defects in membranes. This conclusion is based on the following four observations: (1) since $\mathrm{A} \beta$ clearly forms stepwise ion fluctuations in planar lipid bilayers, it is plausible that it can form similar transmembrane ion fluctuations in cellular membranes. (2) A $\beta$-induced stepwise ion fluctuations in cellular membranes occur at the resting potential of cells (where the activity of intrinsic ion channels is minimal) and persist in the presence of molecules that block the most common ion channel proteins. (3) In contrast, these A $\beta$-induced stepwise ion fluctuations in cellular membranes are blocked by $\mathrm{Zn}^{2+}$ ions and a heptapeptide derived from the sequence of $\mathrm{A} \beta$ (both $\mathrm{Zn}^{2+}$ ions and this heptapeptide block $\mathrm{A} \beta$-induced, stepwise ion flux through artificial bilayers; Arispe et al. 2007). (4) Finally, $A \beta$-induced stepwise ion fluctuations in cellular membranes resemble $\mathrm{A} \beta$-induced stepwise ion fluctuations in artificial membranes with regards to their frequency and amplitude of current events. Based on these observations, we conclude that stepwise ion flux through $\mathrm{A} \beta$-induced pores or membrane defects could contribute to the disruption of $\mathrm{Ca}^{2+}$ homeostasis that is commonly associated with Alzheimer's disease.

Acknowledgments This work was supported by the Wallace $\mathrm{H}$. Coulter Foundation and a NSF Career Award 02-111 (M.M.). M.R.B and J.Y. acknowledge support from the Alzheimer's Disease Research Center (3P50 AG005131) and a grant from the Alzheimer's Association (NIRG-08-91651). P.P. acknowledges a fellowship from the government of Thailand. A.M.S. acknowledges a scholarship from Solvay Inc. We thank James Windak from the University of Michigan, Instrument Services, for measurements of HFIP concentrations by GC-MS.

Open Access This article is distributed under the terms of the Creative Commons Attribution Noncommercial License which permits any noncommercial use, distribution, and reproduction in any medium, provided the original author(s) and source are credited.

\section{References}

Arispe N (2004) Architecture of the Alzheimer's A $\beta$ P ion channel pore. J Membr Biol 197:33-48

Arispe N, Doh M (2002) Plasma membrane cholesterol controls the cytotoxicity of Alzheimer's disease A $\beta \mathrm{P}$ (1-40) and (1-42) peptides. FASEB J 16:1526-1536

Arispe N, Pollard HB, Rojas E (1993a) Giant multilevel cation channels formed by Alzheimer-disease amyloid beta-protein a- $\beta$ P-(1-40) in bilayer-membranes. Proc Natl Acad Sci USA 90:10573-10577

Arispe N, Rojas E, Pollard HB (1993b) Alzheimer-disease amyloid $\beta$-protein forms calcium channels in bilayer-membranesblockade by tromethamine and aluminum. Proc Natl Acad Sci USA 90:567-571

Arispe N, Pollard HB, Rojas E (1996) $\mathrm{Zn}^{2+}$ interaction with Alzheimer amyloid $\beta$ protein calcium channels. Proc Natl Acad Sci USA 93:1710-1715

Arispe N, Diaz JC, Simakova O (2007) A $\beta$ ion channels. Prospects for treating Alzheimer's disease with $\mathrm{A} \beta$ channel blockers. Biochim Biophys Acta 1768:1952-1965

Arispe NJ, Diaz JC, Flora M (2008) Efficiency of histidineassociating compounds for blocking the Alzheimer's A $\beta$ channel activity and cytotoxicity. Biophys J 95:4879-4889

Baglioni S, Casamenti F, Bucciantini M, Luheshi LM, Taddei N, Chiti F, Dobson CM, Stefani M (2006) Prefibrillar amyloid aggregates could be generic toxins in higher organisms. J Neurosci 26:8160-8167

Bahadi R, Farrelly PV, Kenna BL, Curtain CC, Masters CL, Cappai $\mathrm{R}$, Barnham KJ, Kourie JI (2003) $\mathrm{Cu}^{2+}$-induced modification of the kinetics of $\mathrm{A} \beta(1-42)$ channels. Am J Physiol Cell Physiol 285:C873-C880

Barghorn S, Nimmrich V, Striebinger A, Krantz C, Keller P, Janson B, Bahr M, Schmidt M, Bitner RS, Harlan J, Barlow E, Ebert U, Hillen H (2005) Globular amyloid $\beta$-peptide $1-42$ oligomer-a homogenous and stable neuropathological protein in Alzheimer's disease. J Neurochem 95:834-847

Bezprozvanny I, Mattson MP (2008) Neuronal calcium mishandling and the pathogenesis of Alzheimer's disease. Trends Neurosci 31:454-463 
Bhatia R, Lin H, Lal R (2000) Fresh and globular amyloid $\beta$ protein (1-42) induces rapid cellular degeneration: evidence for $\mathrm{A} \beta \mathrm{P}$ channel-mediated cellular toxicity. FASEB J 14:1233-1243

Billups D, Billups B, Challiss RAJ, Nahorski SR (2006) Modulation of Gq-protein-coupled inositol trisphosphate and $\mathrm{Ca}^{2+}$ signaling by the membrane potential. J Neurosci 26:9983-9995

Blake S, Capone R, Mayer M, Yang J (2008) Chemically reactive derivatives of gramicidin A for developing ion channel-based nanoprobes. Bioconjug Chem 19:1614-1624

Bruggemann A, George M, Klau M, Beckler M, Steindl J, Behrends JC, Fertig N (2003) High quality ion channel analysis on a chip with the NPC (c) technology. Assay Drug Dev Technol 1:665673

Capone R, Blake S, Rincon Restrepo M, Yang J, Mayer M (2007) Designing nanosensors based on charged derivatives of gramicidin A. J Am Chem Soc 129:9737-9745

Cheung K-H, Shineman D, Müller M, Cárdenas C, Mei L, Yang J, Tomita T, Iwatsubo T, Lee VMY, Foskett JK (2008) Mechanism of $\mathrm{Ca}^{2+}$ disruption in Alzheimer's disease by presenilin regulation of InsP3 receptor channel gating. Neuron 58:871-883

Demuro A, Mina E, Kayed R, Milton SC, Parker I, Glabe CG (2005) Calcium dysregulation and membrane disruption as a ubiquitous neurotoxic mechanism of soluble amyloid oligomers. J Biol Chem 280:17294-17300

Deshpande A, Mina E, Glabe C, Busciglio J (2006) Different conformations of amyloid $\beta$ induce neurotoxicity by distinct mechanisms in human cortical neurons. J Neurosci 26:60116018

Devi L, Prabhu BM, Galati DF, Avadhani NG, Anandatheerthavarada HK (2006) Accumulation of amyloid precursor protein in the mitochondrial import channels of human Alzheimer's disease brain is associated with mitochondrial dysfunction. J Neurosci 26:9057-9068

Dougherty JJ, Wu J, Nichols RA (2003) $\beta$-Amyloid regulation of presynaptic nicotinic receptors in rat hippocampus and neocortex. J Neurosci 23:6740-6747

Dreses-Werringloer U et al (2008) A polymorphism in CALHM1 influences $\mathrm{Ca}^{2+}$ homeostasis, $\mathrm{A} \beta$ levels, and Alzheimer's disease risk. Cell 133:1149-1161

Durell SR, Guy HR, Arispe N, Rojas E, Pollard HB (1994) Theoretical models of the ion channel structure of amyloid $\beta$-protein. Biophys J 67:2137-2145

Ebihara L, Hall JE, MacDonald RC, McIntosh TJ, Simon SA (1979) Effect of benzyl alcohol on lipid bilayers. A comparisons of bilayer systems. Biophys J 28:185-196

Eliezer D (2006) Amyloid ion channels: a porous argument or a thin excuse? J Gen Physiol 128:631-633

Ennaceur SM, Sanderson JM (2005) Micellar aggregates formed following the addition of hexafluoroisopropanol to phospholipid membranes. Langmuir 21:552-561

Estes DJ, Memarsadeghi S, Lundy SK, Mikol DD, Fox DA, Mayer M (2008) High-throughput profiling of ion channel activity in primary human lymphocytes. Anal Chem 80:3728-3735

Fagan TKB, Corbin D, Hwang W, Glabe C, Nault L, Lal R, Teplow D, Albensi B, Sokolov Y (2006) Alzheimer research forum live discussion: now you see them, now you don't: the amyloid channel hypothesis. J Alzheimers Dis 9:219-224

Fedrizzi L, Lim D, Carafoli E, Brini M (2008) Interplay of the $\mathrm{Ca}^{2+}$. binding protein DREAM with presenilin in neuronal $\mathrm{Ca}^{2+}$ signaling. J Biol Chem 283:27494-27503

Forsythe ID, Lambert DG, Nahorski SR, Linsdell P (1992) Elevation of cytosolic calcium by cholinoceptor agonists in SH-SY5Y human neuroblastoma-cells - estimation of the contribution of voltage-dependent currents. Br J Pharmacol 107:207-214

Furukawa K, Wang Y, Yao PJ, Fu W, Mattson MP, Itoyama Y, Onodera H, D'Souza I, Poorkaj PH, Bird TD, Schellenberg GD
(2003) Alteration in calcium channel properties is responsible for the neurotoxic action of a familial frontotemporal dementia tau mutation. J Neurochem 87:427-436

Gennis RB (1989) Biomembranes, 1st edn. Springer-Verlag, New York

Green KN, Demuro A, Akbari Y, Hitt BD, Smith IF, Parker I, LaFerla FM (2008) SERCA pump activity is physiologically regulated by presenilin and regulates amyloid $\beta$ production. J Cell Biol 181:1107-1116

Gutknecht J, Tosteson DC (1970) Ionic permeability of thin lipid membranes: effects of n-alkyl alcohols, polyvalent cations, and a secondary amine. J Gen Physiol 55:359-374

Guyon A, Rovère C, Cervantes A, Allaeys I, Nahon JL (2005) Stromal cell-derived factor- $1 \alpha$; directly modulates voltagedependent currents of the action potential in mammalian neuronal cells. J Neurochem 93:963-973

Hirakura Y, Lin M-C, Kagan B (1999a) Erratum: Hirakura Y, Lin MC, Kagan BL. 1999. Alzheimer amyloid $\beta$ 1-42 channels: effects of solvent, pH, and congo red. J Neurosci Res 57:458-466. J Neurosci Res 58:726

Hirakura Y, Lin M-C, Kagan BL (1999b) Alzheimer amyloid $\beta 1-42$ channels: effects of solvent, $\mathrm{pH}$, and congo red. J Neurosci Res $57: 458-466$

Inbar P, Yang J (2006) Inhibiting protein-amyloid interactions with small molecules: a surface chemistry approach. Bioorg Med Chem Lett 16:1076-1079

Inbar P, Li CQ, Takayama SA, Bautista MR, Yang J (2006) Oligo(ethylene glycol) derivatives of thioflavin $\mathrm{T}$ as inhibitors of protein-amyloid interactions. ChemBioChem 7:1563-1566

Jang H, Zheng J, Lal R, Nussinov R (2008) New structures help the modeling of toxic amyloidß ion channels. Trends Biochem Sci 33:91-100

Joslin G, Krause J, Hershey A, Adams S, Fallon R, Perlmutter D (1991) Amyloid- $\beta$ peptide, substance $\mathrm{P}$, and bombesin bind to the serpinenzyme complex receptor. J Biol Chem 266:21897-21902

Kagan BL, Hirakura Y, Azimov R, Azimova R, Lin M-C (2002) The channel hypothesis of Alzheimer's disease: current status. Peptides 23:1311-1315

Kagan BL, Azimov R, Azimova R (2004) Amyloid peptide channels. J Membr Biol 202:1-10

Kawahara M, Kuroda Y, Arispe N, Rojas E (1996) Direct incorporation of amyloid $\beta$-protein cation channels into excised membrane patches from GnRH neurons. Biophys J 70:S104

Kawahara M, Arispe N, Kuroda Y, Rojas E (1997) Alzheimer's disease amyloid $\beta$-protein forms $\mathrm{Zn}(2+)$-sensitive, cation-selective channels across excised membrane patches from hypothalamic neurons. Biophys J 73:67-75

Kawahara M, Kuroda Y, Arispe N, Rojas E (2000) Alzheimer's $\beta$ amyloid, human islet amylin, and prion protein fragment evoke intracellular free calcium elevations by a common mechanism in a hypothalamic GnRH neuronal cell line. J Biol Chem 275: 14077-14083

Kayed R, Head E, Thompson JL, McIntire TM, Milton SC, Cotman CW, Glabe CG (2003) Common structure of soluble amyloid oligomers implies common mechanism of pathogenesis. Science 300:486-489

Kayed R, Sokolov Y, Edmonds B, McIntire TM, Milton SC, Hall JE, Glabe CG (2004) Permeabilization of lipid bilayers is a common conformation-dependent activity of soluble amyloid oligomers in protein misfolding diseases. J Biol Chem 279:46363-46366

Khachaturian ZS (1987) Hypothesis on the regulation of cytosol calcium concentration and the aging brain. Neurobiol Aging 8:345-346

Khachaturian ZS (1989) Introduction and overview on calcium, membranes, aging, and Alzheimer's disease. Ann NY Acad Sci 568:1-4 
Koh J-y, Yang LL, Cotman CW (1990) $\beta$-Amyloid protein increases the vulnerability of cultured cortical neurons to excitotoxic damage. Brain Res 533:315-320

Kourie J, Henry C, Farrelly P (2001) Diversity of amyloid $\beta$ protein fragment [1-40]-formed channels. Cell Mol Neurobiol 21:255-284

Kourie J, Culverson A, Farrelly P, Henry C, Laohachai K (2002) Heterogeneous amyloid-formed ion channels as a common cytotoxic mechanism. Cell Biochem Biophys 36:191-207

Kurganov B, Doh M, Arispe N (2004) Aggregation of liposomes induced by the toxic peptides Alzheimer's $A \beta$ s, human amylin and prion (106-126): facilitation by membrane-bound GM1 ganglioside. Peptides 25:217-232

Lal R, Lin H, Quist AP (2007) Amyloid $\beta$ ion channel: 3D structure and relevance to amyloid channel paradigm. Biochim Biophys Acta 1768:1966-1975

Lam FC, Liu R, Lu P, Shapiro AB, Renoir J-M, Sharom FJ, Reiner PB (2001) $\beta$-Amyloid efflux mediated by p-glycoprotein. J Neurochem 76:1121-1128

Lecoeur H, Chauvier D, Langonne A, Rebouillat D, Brugg B, Mariani J, Edelman L, Jacotot E (2004) Dynamic analysis of apoptosis in primary cortical neurons by fixed- and real-time cytofluorometry. Apoptosis 9:157-169

Lin M-cA, Kagan BL (2002) Electrophysiologic properties of channels induced by $\mathrm{A} \beta 25-35$ in planar lipid bilayers. Peptides 23:1215-1228

Lin $\mathrm{H}$, Zhu YJ, Lal R (1999) Amyloid $\beta$-protein (1-40) forms calcium-permeable, $\mathrm{Zn}^{2+}$-sensitive channel in reconstituted lipid vesicles. Biochemistry 38:11189-11196

Lin H, Bhatia R, Lal R (2001) Amyloid $\beta$ protein forms ion channels: implications for Alzheimer's disease pathophysiology. FASEB J 15:2433-2444

Lopez JR, Lyckman A, Oddo S, LaFerla FM, Querfurth HW, Shtifman A (2008) Increased intraneuronal resting $\left[\mathrm{Ca}^{2+}\right]$ in adult Alzheimer's disease mice. J Neurochem 105:262-271

Luo J, Miller MW (1997) Differential sensitivity of human neuroblastoma cell lines to ethanol: correlations with their proliferative responses to mitogenic growth factors and expression of growth factor receptors. Alcohol Clin Exp Res 21:1186-1194

Mark R, Hensley K, Butterfield D, Mattson M (1995) Amyloid $\beta$ peptide impairs ion-motive ATPase activities: evidence for a role in loss of neuronal $\mathrm{Ca}^{2+}$ homeostasis and cell death. J Neurosci 15:6239-6249

Marx J (2007) Alzheimer's disease-fresh evidence points to an old suspect: calcium. Science 318:384-385

Mathie A, Wooltorton JRA, Watkins CS (1998) Voltage-activated potassium channels in mammalian neurons and their block by novel pharmacological agents. Gen Pharmacol 30:13-24

Mattson MP, Chan SL (2003) Calcium orchestrates apoptosis. Nat Cell Biol 5:1041-1043

Mattson M, Cheng B, Davis D, Bryant K, Lieberburg I, Rydel R (1992) $\beta$-Amyloid peptides destabilize calcium homeostasis and render human cortical neurons vulnerable to excitotoxicity. J Neurosci 12:376-389

Mayer M, Kriebel JK, Tosteson MT, Whitesides GM (2003) Microfabricated teflon membranes for low-noise recordings of ion channels in planar lipid bilayers. Biophys J 85:2684-2695

Mayer M, Semetey V, Gitlin I, Yang J, Whitesides GM (2008) Using ion channel-forming peptides to quantify protein-ligand interactions. J Am Chem Soc 130:1453-1465

McDonald RL, Vaughan PFT, Peers C (1994) Muscarinic (M(1)) receptor-mediated inhibition of $\mathrm{K}+$-evoked [H-3] noradrenaline release from human neuroblastoma (SH-SY5Y) cells via inhibition of L-type and $\mathrm{N}$-type $\mathrm{Ca}^{2+}$ channels. $\mathrm{Br} \mathrm{J}$ Pharmacol 113:621-627

McDonald RL, Vaughan PFT, Beck-Sickinger AG, Peers C (1995) Inhibition of $\mathrm{Ca}^{2+}$ channel currents in human neuroblastoma
(SH-SY5Y) cells by neuropeptide $\mathrm{Y}$ and a novel cyclic neuropeptide $Y$ analogue. Neuropharmacology 34:1507-1514

Micelli S, Meleleo D, Picciarelli V, Gallucci E (2004) Effect of sterols on $\beta$-amyloid peptide (A $\beta \mathrm{P} 1-40)$ channel formation and their properties in planar lipid membranes. Biophys J 86:2231-2237

Michikawa M, Gong J-S, Fan Q-W, Sawamura N, Yanagisawa K (2001) A novel action of Alzheimer's amyloid $\beta$-protein $(\mathrm{A} \beta)$ : oligomeric A $\beta$ promotes lipid release. J Neurosci 21:7226-7235

Mirzabekov T, Lin MC, Yuan WL, Marshall PJ, Carman M, Tomaselli K, Lieberburg I, Kagan BL (1994) Channel formation in planar lipid bilayers by a neurotoxic fragment of the $\beta$-amyloid peptide. Biochem Biophys Res Commun 202:1142-1148

Mobley DL, Cox DL, Singh RRP, Maddox MW, Longo ML (2004) Modeling amyloid $\beta$-peptide insertion into lipid bilayers. Biophys J 86:3585-3597

Montal M, Mueller P (1972) Formation of bimolecular membranes from lipid monolayers and a study of their electrical properties. Proc Natl Acad Sci USA 69:3561-3566

Morimoto T, Ohsawa I, Takamura C, Ishiguro M, Nakamura Y, Kohsaka S (1998) Novel domain-specific actions of amyloid precursor protein on developing synapses. J Neurosci 18:93869393

Morris CE, Juranka PF (2007) Lipid stress at play: mechanosensitivity of voltage-gated channels. In: Mechanosensitive ion channels, Pt B, pp 297-338

Mueller P, Rudin DO, Tien HT, Wescott WC (1962) Reconstitution of cell membrane structure in vitro and its transformation into an excitable system. Nature 194:979-980

Nimmrich V, Grimm C, Draguhn A, Barghorn S, Lehmann A, Schoemaker H, Hillen H, Gross G, Ebert U, Bruehl C (2008) Amyloid $\beta$ oligomers (A $\beta 1-42$ globulomer) suppress spontaneous synaptic activity by inhibition of P/Q-type calcium currents. J Neurosci 28:788-797

Novarino G, Fabrizi C, Tonini R, Denti MA, Malchiodi-Albedi F, Lauro GM, Sacchetti B, Paradisi S, Ferroni A, Curmi PM, Breit SN, Mazzanti M (2004) Involvement of the intracellular ion channel CLIC1 in microglia-mediated $\beta$-amyloid-induced neurotoxicity. J Neurosci 24:5322-5330

Palop JJ, Chin J, Roberson ED, Wang J, Thwin MT, Bien-Ly N, Yoo J, Ho KO, Yu G-Q, Kreitzer A, Finkbeiner S, Noebels JL, Mucke L (2007) Aberrant excitatory neuronal activity and compensatory remodeling of inhibitory hippocampal circuits in mouse models of Alzheimer's disease. Neuron 55:697-711

Pollard HB, Rojas E, Arispe N (1993) A new hypothesis for the mechanism of amyloid toxicity, based on the calcium-channel activity of amyloid-beta protein (a- $\beta$-P) in phospholipid-bilayer membranes. In: Alzheimer's disease: amyloid precursor proteins, signal transduction, and neuronal transplantation, pp 165-168

Querfurth HW, Jiang J, Geiger JD, Selkoe DJ (1997) Caffeine stimulates amyloid $\beta$-peptide release from $\beta$-amyloid precursor protein-transfected HEK293 cells. J Neurochem 69:1580-1591

Quist A, Doudevski I, Lin H, Azimova R, Ng D, Frangione B, Kagan B, Ghiso J, Lal R (2005) Amyloid ion channels: a common structural link for protein-misfolding disease. Proc Natl Acad Sci USA 102:10427-10432

Reeve HL, Vaughan PFT, Peers C (1994) Calcium-channel currents in undifferentiated human neuroblastoma (SH-SY5Y) cellsactions and possible interactions of dihydropyridines and omegaconotoxin. Eur J Neurosci 6:943-952

Reeve Hl, Vaughan PFT, Peers C (1995) Inhibition of N-type $\mathrm{Ca}^{2+}$ channel currents in human neuroblastoma (SH-SY5Y) cells by muscarine via stimulation of $\mathrm{M} 3$ receptors. Neuropharmacology 34:319-326

Rhee SK, Quist AP, Lal R (1998) Amyloid $\beta$ protein-(1-42) forms calcium-permeable, $\mathrm{Zn}^{2+}$-sensitive channel. J Biol Chem 273: 13379-13382 
Rovira C, Arbez N, Mariani J (2002) A $\beta(25-35)$ and A $\beta(1-40)$ act on different calcium channels in CA1 hippocampal neurons. Biochem Biophys Res Commun 296:1317-1321

Saluja I, Saunders TL, Turner RS (2006) Modulation of neuronal APP metabolism by X11 $\alpha /$ mint-1/APBA1. In: Alzheimer's disease: new advances. Medimond international proceedings

Schmidt C, Mayer M, Vogel H (2000) A chip-based biosensor for the functional analysis of single ion channels. Angew Chem Int Ed 39:3137-3140

Simakova O, Arispe NJ (2006) Early and late cytotoxic effects of external application of the Alzheimer's $\mathrm{A} \beta$ result from the initial formation and function of $\mathrm{A} \beta$ ion channels. Biochemistry 45:5907-5915

Simakova O, Arispe NJ (2007) The cell-selective neurotoxicity of the Alzheimer's A peptide is determined by surface phosphatidylserine and cytosolic ATP levels. Membrane binding is required for A $\beta$ toxicity. J Neurosci 27:13719-13729

Sokolov YV, Kayed R, Kozak A, Edmonds B, McIntire TM, Milton S, Cahalan M, Glabe CG, Hall JE (2004) Soluble amyloid oligomers increase lipid bilayer conductance by increasing the dielectric constant of the hydrocarbon core. Biophys J 86:382A$382 \mathrm{~A}$

Sokolov Y, Kozak JA, Kayed R, Chanturiya A, Glabe C, Hall JE (2006) Soluble amyloid oligomers increase bilayer conductance by altering dielectric structure. J Gen Physiol 128:637-647

Stains CI, Mondal K, Ghosh I (2007) Molecules that target betaamyloid. ChemMedChem 2:1674-1692

Stutzmann GE (2007) The pathogenesis of Alzheimers disease-is it a lifelong "Calciumopathy"? Neuroscientist 13:546-559

Stutzmann GE, Smith I, Caccamo A, Oddo S, LaFerla FM, Parker I (2006) Enhanced ryanodine receptor recruitment contributes to $\mathrm{Ca}^{2+}$ disruptions in young, adult, and aged Alzheimer's disease mice. J Neurosci 26:5180-5189

Stutzmann GE, Smith I, Caccamo A, Oddo S, Parker I, Laferla F (2007) Enhanced ryanodine-mediated calcium release in mutant PS1-expressing Alzheimer's mouse models. Ann NY Acad Sci 1097:265-277

Toselli M, Tosetti P, Taglietti V (1996) Functional changes in sodium conductances in the human neuroblastoma cell line SH-SY5Y during in vitro differentiation. J Neurophysiol 76:3920-3927

Tosetti P, Taglietti V, Toselli M (1998) Functional changes in potassium conductances of the human neuroblastoma cell line
SH-SY5Y during in vitro differentiation. J Neurophysiol 79:648-658

Tu H, Nelson O, Bezprozvanny A, Wang Z, Lee S-F, Hao Y-H, Serneels L, De Strooper B, Yu G, Bezprozvanny I (2006) Presenilins form ER $\mathrm{Ca}^{2+}$ leak channels, a function disrupted by familial Alzheimer's disease-linked mutations. Cell 126:981993

Ueda I, Yoshida T (1999) Hydration of lipid membranes and the action mechanisms of anesthetics and alcohols. Chem Phys Lipids 101:65-79

Ueda K, Shinohara S, Yagami T, Asakura K (1997) Amyloid $\beta$ protein potentiates $\mathrm{Ca}^{2+}$ influx through L-type voltage-sensitive $\mathrm{Ca}^{2+}$ channels: a possible involvement of free radicals. J Neurochem 68:265-271

Valincius G, Heinrich F, Budvytyte R, Vanderah DJ, McGillivray DJ, Sokolov Y, Hall JE, Losche M (2008) Soluble amyloid $\beta$ oligomers affect dielectric membrane properties by bilayer insertion and domain formation: implications for cell toxicity. Biophys J 95:4845-4861

Verdier Y, Zarándi M, Penke B (2004) Amyloid $\beta$-peptide interactions with neuronal and glial cell plasma membrane: binding sites and implications for Alzheimer's disease. J Pept Sci 10:229-248

Wang H-Y, Lee DHS, Davis CB, Shank RP (2000) Amyloid peptide A $\beta 1-42$ binds selectively and with picomolar affinity to $\alpha 7$ nicotinic acetylcholine receptors. J Neurochem 75:1155-1161

Yankner BA, Duffy LK, Kirschner DA (1990a) Neurotrophic and neurotoxic effects of amyloid $\beta$ protein: reversal by tachykinin neuropeptides. Science 250:279-282

Yankner BA, Caceres A, Duffy LK (1990b) Nerve growth factor potentiates the neurotoxicity of $\beta$ amyloid. Proc Natl Acad Sci USA 87:9020-9023

Ye C, Ho-Pao CL, Kanazirska M, Quinn S, Rogers K, Seidman CE, Seidman JG, Brown EM, Vassilev PM (1997) Amyloid- $\beta$; proteins activate $\mathrm{Ca}^{2+}$-permeable channels through calciumsensing receptors. J Neurosci Res 47:547-554

Zhu YJ, Lin H, Lal R (2000) Fresh and nonfibrillar amyloid $\beta$ protein (1-40) induces rapid cellular degeneration in aged human fibroblasts: evidence for $\mathrm{A} \beta \mathrm{P}$-channel-mediated cellular toxicity. FASEB J 14:1244-1254 